\title{
МЕХАНІЗМИ ЕСТЕТИЧНОї РЕГУЛЯЦІї
}

\section{О.А. Єрьоміна}

В сучасній філософській літературі існують досить різноманітні погляди на розуміння сутності естетичних процесів в суспільстві. Одні дослідники витлумачують естетичні явища як соціально значимі і такі, що впливають на соціальний розвиток (див., напр. [3], [4], [5], [6]), у той час як інші наголошують на тому, що естетичні відносини проявляються у «незацікавленій» емоції ([1], [7], [8]). Тут виникає певне протиріччя, яке більшість дослідників просто ігнорують і розуміють естетичне сприйняття як унікальне, неповторне, що має особистісний зміст, як епіфеномен. Проте, слід зауважити, що впродовж існування соціуму вся соціальна практика використовувала естетичну сферу як соціальний регулятор у різноманітних галузях: політиці, моралі, економіці, педагогіці, релігії, спорті та інших.

Таким чином, необхідним методологічним моментом виявляється визначення механізму зв'язку соціальних регулятивних структур з естетичною сферою. На наш погляд вирішенню цієї задачі допоможе розкриття сутності поняття «естетична регуляція». Без розгляду зв'язку соціальної регуляції і естетичної сфери суспільного життя неможливе розумінні сутності соціорегулятивніх механізмів. У зв'язку з цим соціальну регуляцію доцільно визначати як емоційну регуляцію, як «управління потоками інтересів людей шляхом спеціально створюваних у суспільстві систем емоційного забарвлення образів: політичного, релігійного, морального, утилітарно-практичного, естетичного і т. д.» $[5$, c. 9]. Суспільство виступае творцем і замовником естетично грамотних людей і формуе наочні області, що вимагають естетичної діяльності, тому для підтримки соціальної стабільності необхідним стає вироблення механізмів естетичної регуляції. Саме аналізу цієї проблеми 
присвячена наша стаття.

Для розвитку структурних елементів естетичної свідомості, як і свідомості взагалі, необхідне закріплення тих або інших психологічних процесів в такі стійкі фізіологічні механізми, які, володіючи властивостями константності, в той же час сприяли б тому, щоб естетична свідомість могла виявляти гнучкість, динамічність, рухливість, тобто могла перебувати в стані розвитку. Елементи свідомості, що спираються на міцну і стійку психофізіологічну базу, виявляються здатними виконувати регуляторні і активізуючі діяльність мозку функції.

У структурі естетичної свідомості саме таку базу має естетичне почуття, яке є концентрованим проявом і закріпленням сили емоцій. Естетичне почуття як важливий психічний процес пов'язуе в нерозривну єдність особистість і навколишній світ, індивіда й умови його існування не лише на біологічному, але і на соціальному рівні, оскільки через естетичне почуття, в якому концентруються результати переживання і емоційних станів, відбувається поточна регуляція поведінки індивіда. Естетичне почуття вносить своєрідний порядок в потік емоційних станів і виконуе роль регулятора емоційного життя індивіда. Через естетичне почуття формуеться здатність особистості емоційно реагувати на предмети і явища, що мають для людини не біологічну, матеріальну, а соціальну і духовну значимість. Стандартні життеві ситуації вимагають типових способів їх розв'язання. Це дозволяе стимулювати задану поведінкову активність людей за допомогою об'єктів естетичної сфери, що здатні викликати певні емоції і почуття.

У основі механізму естетичної регуляції якраз і лежить наявність естетичного почуття, яке «зростає» $з$ біологічних задоволень і незадоволень в процесі практичного перетворення дійсності внаслідок подвійного «перенесення» емоцій. «Спочатку з'являються утилітарні емоції, як наслідок „перенесення" вроджених, біологічних емоцій з біологічно значущих цілей на біологічно нейтральні, а потім утилітарні емоції перетворюеться на естетичні, внаслідок повторного „перенесення“ емоцій з практично значущих на практично нейтральні властивості дійсності» $[4$, с. 160$]$. Повторне перенесення емоції стає можливим завдяки появі в психіці особливих образів, які О.П. Воєводін називає «естетичними абстракціями». Естетичні абстракції виникають в процесі практичного освоєння навколишнього світу і $е$ узагальненими і абстрагованими від реального контексту перцептивними образами окремої якості або комплексу якостей (лінія, колір, симетрія, ритм, інтонація і т.п.), що викликае стійку емоційну оцінку, і відповідає практичному значенню даної якості. Слід зазначити, що структурні поєднання 
звуків, кольорів або ритмічних рухів діють на істоти як сигнал до тієї або іншої дії, і ці сигнали входять в сприйняття істот не в своєму безпосередньому природному стані, а перетворються в стан, або код, чуттевого естетичного подразника. При цьому зберігається структура природних явищ. Це $е$ «структурний ізоморфізм» або «ізоморфно повторовальна структура» [14, с. 13], яка своєю образністю і подібністю впливае на поведінку індивіда. Цю ж роль відіграє і «естетична абстракція» як «своєрідний чуттєво-емоційний знак, емоційна константа, сплав образу, якості і емоції, що дозволяє на рефлекторній основі збуджувати емоції за допомогою нейтральних в практичному відношенні якостей, якщо вони виявляються схожими на реальні практичні якості» $[4$, с. 161$]$. Внаслідок єдності відображення якостей дійсності і певних емоцій виникає «естетичний образ», який «по суті своїй базується на практичній оцінці якостей і явищ дійсності, його зміст продиктований практикою, збігається з практичним значенням об'єкту сприйняття, з тією лише різницею, що емоція викликається штучним шляхом, за допомогою нейтральних в практичному відношенні якостей дійсності» $[4$, с. 160$]$.

Традиційно проблема образу розглядалася в психологіі. Предметність первинного, сенсорно-перцептивного образу пов'язана 3 тим, що, як писав I.M. Сеченов, орган чуття (наприклад, око) відчуває не сам себе (не зміни в сітчатці ока), а зовнішню причину почуттів $[12$, c. 433]. За своїм змістом естетичний образ, так само як сенсорно-перцептивний образ, предметний. Але, на відміну від почуття і сприйняття, які «нав'язані нашому розуму ззовні» і через це презентуються свідомості як жорстко і однозначно віднесені до об'єктивної реальності, естетичний образ має мов би самостійне існування.

Формування естетичного образу відбувається на основі узагальнення і абстракцій. Внаслідок багаторазового сприйняття предметів однієї і тієї ж категорії відбувається селекція їх ознак: випадкові ознаки відсіваються, а фіксуються лише характерні і тому найбільш інформативні. В естетичному образі змінюеться структура образу об'єкта: одні його ознаки мов би підкреслюються, посилюються, інші редукуються, тобто відбувається схематизація предметного образу. Естетичний образ має вирішальне значення при формуванні образів-еталонів поведінки, концептуальних моделей, необхідних для стимулювання активності. Естетичний образ виступає як стимул, спонукальна сила, що примушуе організовувати життя певним чином. Реакцією на присутність естетичного образу стає естетичне почуття. Емоційно ми реагуємо не лише на те, що є естетичним, проте естетичні переживання 
опосередковуються не тільки пізнанням об'єкту, але значною мірою і оцінкою.

Образ красивого предмету, проникаючи в структуру почуттів, відповідно організовуе їх. Не приносячи жодної утилітарної користі, естетичні цінності діють на людину не менш сильно, але інакше-вони створюють, спрямовують організованість сприйняття і уваги. Естетична насолода безкорислива. Естетичне явище впливає на нас як організуючий імпульс, регулюючи відповідну настроєність нашого духовного світу. Естетичні враження не існують поза тілом людини. Вони є один із станів організму, що відрізняється від інших способом представлення емоції в свідомості. Усвідомлення естетичного означае передусім якісне осмислення своєрідності того чуттєвого стану, який відчуває дослідник і лише потім вже визначення об'єкту, з приводу якого виникає у нього естетичне враження, а не навпаки. Отже, усвідомлення і подальша взаємна кореляція залежності характеру естетичного переживання, його сенсу і значення, від структури естетичного об'єкту повинні стати основою теоретико-естетичного дослідження проблем естетичної регуляції.

Для штучного відтворення емоційно насичених фрагментів соціальної практики використовуються естетичні абстракції. При цьому зміст естетичних образів наповнюеться предметним, соціально-практичним змістом, i, отже, з'являється можливість і необхідність його раціональної інтерпретації. Поява в суспільстві складних комплексів естетичних аб́стракцій в сукупності з предметним змістом носить характер організуючого процесу і породжуе об'єктивну необхідність його раціонального регулювання.

Розглянемо дію механізму естетичної регуляції на прикладі створення художнього образу у творах мистецтва. Ще Л.С. Виготській відзначав, що регулятивна, соціалізуюча функція мистецтва базуеться на емоційній основі. Емоції в мистецтві не побічний елемент, а сама сутність, центральний момент. Арістотель зазначав, що мистецтво очищає шляхом співчуття і страху, тобто, впливаючи на чуттєво-емоџійну сферу людини. «Пізнаючи форми емоційного ставлення до дійсності, мистецтво є ефективним засобом формування і перебудови системи соціальної орієнтації особистості. Якщо наука пояснюе устрій навколишнього світу, то мистецтво формує у людей стимули соціально-практичної діяльності», - зазначають О.П. Воєводін і В.О. Іллюшин [3, с. 76]. На їхню думку, у витворі мистецтва автор створюе певні образи, але для активної соціальної діяльності «необхідно пов'язати ці образи з потребами і інтересами людини як істоти«, а це можливо лише шляхом 
впливу на емоційну сферу, оскільки «саме емоції спонукають людину до дії». Тому «чим багатший емоційний світ людини, тим більш різноманітні в його психіці зв'язки образів навколишнього світу і емоцій, тим більшу соціальну активність проявляе ця людина» [3, с. 73-81].

Недорозвиненість емоційної сфери робить людину або аморальним егоїстом, або сухим педантом. Звертаючись до думок і почуттів людини, до $\dddot{1}$ внутрішнього життя, мистецтво формуе і відточуе $\dddot{1}$ смак, який виявляеться в практичній діяльності людини. У мистецтві втілюеться сконцентрований творчий досвід людства в прекрасній формі. Саме цим пояснюеться той факт, чому «людина збіднена, з нерозвиненим індивідуальне багатством смаку, задовольняеться скромною нормою, голодним пайком почуттів і прагне розповсюдити цю норму на всіх людей, тоді як людина духовно багата завжди поважає неповторність іншої особистості, не задовольняеться нормою як чимось завершеним, а знаходиться в абсолютному русі становлення» [9, с. 17].

Регуляція, виховання через мистецтво стає можливим тому, що художник в своєму творі відображуе типові життєві ситуації, які формують в людях стереотипні реакції. Естетичні почуття людини і виявляються дійсно суспільними почуттями. «Лише завдяки предметно розгорненому багатству людської істоти розвивається, а частково і вперше породжується, багатство суб'єктивної людської чуттевості: музичне вухо, око, щцо відчувае красу форми, - тобто, такі почуття, які здатні до людської насолоди і які затверджують себе як людські сутнісні сили. Бо не лише п'ять зовнішніх почуттів, але і так звані духовні почуття, практичні почуття (воля, любов та ін.), - отже, людське почуття, людяність почуттів виникають лише завдяки наявності відповідного предмету, завдяки олюдненій природі» [9, с.9].

Мистецтво об'єднуе реальні явища, випадки, характери, але не копіюе їх, а пропускае крізь призму естетичних ідеалів. Художник, як член певного суспільства, вкладає в свій твір ті ідеали, які несе дане суспільство. Художник захоплюе слухача, читача, глядача своїми ідейними симпатіями і тим самим переконуе його в істинності і красі своїх переконань.

Використовуючи в своєму арсеналі ті або інші засоби, художник цілеспрямовано впливає на емоційну сферу глядача, слухача, який крім своєї волі потрапляе в сферу емоційного впливу. 3 цієї причини люди намагалися використовувати мистецтво в регулятивних цілях з незапам'ятних часів. Ще в Давній Греції при лікуванні так званих душевних хвороб, широко застосовувалося мистецтво. Піфагор, за свідченнями сучасників, володів мистецтвом гармонізувати душевні стани, виправ- 
ляти погані схильності за допомогою музики. Методика Піфагора полягала в зануренні в стан «пацієнта», в знаходженні відповідних цьому стану мелодій-ритмів і поступовій перебудові їх з метою виведення людини 3 критичного стану, прояснення. Але для цього автор музичного твору не повинен просто слідувати за пристрастями людей, а сам повинен вести їх за собою. Саме ця думка знайшла символічне втілення у міфі про Орфея.

В мистецтві, крім того, щоб повідомити про ту або іншу цінність, художній образ повинен обов'язково викликати емоційну оцінку, для цього вживаються такі засоби, види художньої мови як естетичні знаки, до яких відносяться ритми і мелодії інструментальної музики, танцювальні па, колорит живопису, співвідношення об'ємів і фігур архітектурного твору, службовці для передачі емоційної інформації. Естетичні знаки - це організовані естетичним кодом естетичні сигнали. В якості останніх виступають естетичні абстракџії (лінії, звуки, кольори, форми). Самі по собі вони не несуть ніякої інформації, і лише оформлені відповідно з естетичним кодом починають виконувати свою регулюючу функцію. Розшифровка естетичного коду дозволить розкрити механізм регулювання поведінки людей. У минулому практика неусвідомленого впливу за допомогою сигналів естетичної інформації використовувалася, наприклад, жерцями, які користувалися орнаментальними мотивами, щоб колірною гамою і ритмікою візерунків впливати на волю людей. Так само чинить і художник, моделюючи дійсність, 3 наміром спонукати людину через аперцепцію.

Чому ж певні поеднання кольорів і звуків, стаючи естетичними знаками здатні впливати на духовний і інтелектуальний світ людини. Розглянемо, наприклад, орнамент, як вид мистецтва. Створюючи знаряддя праці і побутові речі, людина покривае їх відповідними орнаментами або візерунками. «На перший погляд явище це представляється надзвичайно загадковим. Чому потрібні якісь цятки, щербинки і т. д. на цьому горщику? Хіба від цього їжа, яка в ньому вариться, буде ситнішою або смачнішою? Ні. Чому ж людина витрачає додаткову працю, щоб зробити горщик прикрашеним, красивим?..» [10, с. 17]. На це питання намагався відповісти ще А.В. Луначарський у своїй роботі «Основи позитивної естетики». Звичайно, «не від надміру сил», як про це писав А.В.Луначарський, селянин, будуючи хату для житла, покривав її в той же час візерунками дерев'яного орнаменту. Людині необхідно було передати «заряд» організаційного початку своєї творчої енергії іншим людям. I він повинен був знайти засоби для відбиття цього початку. Він знаходив їх, створюючи орнаментальні узори і мо- 
тиви. Кожен мотив орнаменту співвідноситься, порівнюеться з попереднім і наступним, і таке повторення схожих елементів, проходячи через весь орнаментальний узор, виступало як організуюча, об'єднуюча сила. У чому ж полягае естетична цінність орнаменту? При спогляданні орнаменту в свідомості виникае естетичний образ, що впливае на духовний світ. Ритміка ліній орнаменту в сприйнятті людини переходить в своєрідні імпульси, що перетворюються в код естетичних знаків, які настроюють систему людських почуттів і створюють певне емоційне напруження. Проникаючи в сутнісь впливу цієї мобілізаційної сили орнаментально-ритмічних структур на систему людських почуттів, ми тим самим пояснюемо «гіпнотизм» дії орнаментальних ритмів.

Те ж саме справедливо і відносно мистецтва танцю. Ритми танцю стають спонукаючою і організуючою силою. П.В. Симонов пише про первісний танець: «Група первісних мисливців виконуе ритуальний танок. Час від часу воїни пронизують дротиками фігуру мамонта, намальовану на стіні (такі зображення із слідами ударів не раз знаходили археологи). Учасники танка не отримали додаткових відомостей про те, як краще полювати на мамонта. Мабуть, лише наймолодші могли набути якогось прагматичного досвіду. Але після танка на боротьбу 3 мамонтом вирушає не стадо тремтячих тварюк, готових розбігтися при першій же невдачі, а колектив воїнів, упевнених в перемозі (адже мамонт на стіні печери вже убитий!), охоплені бойовим азартом, сповнених натхнення і сил» $[13$, с. 69$]$. Ми бачимо, що ритміка первісного танка має величезну силу емоційного впливу, розкриває естетичну значущість танка в його структурно-логічній значущості.

Безумовно, спочатку регуляторні, організуючі естетичні сили зосереджувалися для людей, в деяких природних властивостях ритмічних явищ, і лише пізніше - в ритміці створюваного орнаменту, в танцях, в звуковій ритміці пісень і мелодій. У зв'язку з цим А.Н. Веселовський зазначав, що «характер прадавніх пісень відповідав потребі дати вихід, полегшення, вираження фізичної і психічної енергії, що накопичилася, шляхом ритмічно впорядкованих звуків і рухів» [2, с. 201]. Мотиви і ритми стародавніх пісень виконували регуляторну, організуючу функцію емоційних станів, шляхом ритмічно впорядкованих звуків, які були відповідними імпульсами, що настроюють почуття людей. Ритм естетично впливає на нас тоді, коли, ізоморфно перетворюючись у відповідні психологічні імпульси, здатний привести нас у відповідний психічний стан.

У таких видах мистецтва як література і живопис розкриття сюжету дозволяе відбити соціальні проблеми людського буття. Тому вони 
стають не лише могутніми засобами пізнавальної активності, але і за допомогою художніх образів дають можливість керувати емоційними процесами шляхом виховання необхідних суспільству почуттів і емоцій. Естетично-регулятивна роль мистецтва якраз і визначається тим, наскільки гостро і наскільки типово в художніх образах і сюжетах розкриваються життєві колізії і моральні проблеми. Естетика фактично стала займатися взаемовідношенням художнього образу і реального світу.

Образ - це основа мистецтва, його міцний фундамент. Проте $\boldsymbol{\varepsilon}$ в мистецтва і інші засоби впливу. Сприймаючи своє образне пізнання світу не лише як пізнавальну цінність, художник прагне до того, щоб структура його творів ставала для читачів і глядачів саме естетичнорегулюючим початком. Естетична регуляція емоційності є не менш важливим чинником, ніж пізнання. Це підтверджуе, що мистецтво покликане задовольняти дві потреби: пізнавальну і регулятивно-організуючу. Це відбувається через образність і естетичну регуляцію, які в мистецтві тісно пов'язані відношенням ізоморфізму: естетична регуляція виражається через образність, а образність складає основу регуляції.

Образність вивчена в мистецтва досить грунтовно, а ось на регулятивні можливості естетичного образу акцент не ставився. Мистецтво з'являеться лише тоді, коли діє естетично-регулюючий початок, що проводить спрямоване перетворення всієї структури образного і раціонально мислення і що перетворюе образне мислення письменника, живописця, скульптора на естетичну цінність. На думку французького дослідника А. Моля [11, с. 203], у витворі мистецтва об'єднуються два самостійних початки. Одне відноситься до того, що повідомляеться або зображається у витворі мистецтва, тобто до фактичного сюжетного розкриття образів, характерів, життевих ситуацій і т. Д. А. Моль назвав це комунікативною інформацією [11, с. 203], що припускає точний переказ, оскільки заснована на символах і законах логіки і психології. Другий початок у витворах мистецтва представляе власне естетичну інформацію. Ії практично не можна переказати за допомогою інших способів вираження, проте можливо раціонально осмислити.

Розвиток людської свідомості і форм ідейної виразності призвів до зростання ролі раціонального моменту. Абсолютизація раціональних принципів в аналізі явищ дійсності привела до недооцінки багатьох сощіальних процесів. «Заклинальні» форми виразності, як форми особливого впливу на людей збереглися не лише в релігійній і культовій практиці, вони взяті на озброєння сучасними політтехнологами, 
іміджмейкерами, рекламодавцями і іншими соціальними інститутами, де чисто раціональне управління потоками інтересів людей не може принести ефективного результату, де використання виразних засобів впливу стае обов'язковим елементом.

Естетичний початок здатний збуджувати могутні духовні потенції в наших почуттях і думках, здатний організовувати і стимулювати їх. Немало явищ такого порядку зазвичай спостерігається в житті, коли ті або інші об'єкти естетичної сфери своїм організованим ладом відображення життєвих явищ здатні впливати на поведінку людей. Розкриття механізмів дії естетичної регуляції дозволяе прогнозувати вчинки людей. Тому необхідна подальша розробка механізмів естетичної регуляції в естетиці, культурології, соціології, педагогіки, та інших наукових дисциплінах, в центрі уваги вивчення яких стоїть людина.

\section{1 Бібліографія}

[1] Бычков B.B. По поводу тысячелетия христианской культуры. Эстетический ракурс // Полигнозис. - 1999. - №3. - С. 3848.

[2] Веселовский А.Н. Историческая поэтика. - М.: Изд-во АН СССР, 1940.

[3] Воебодин А.П., Илюшин В.А. О соотношении эстетического и утилитарного // Философские науки. - 1985. - ำ 1. - С. 73-81.

[4] Воебодин А.П. Становление рационально-теоретических форм в структуре художественного созанния: опыт историко-генетической реконструкции. - Луганск: Изд-во ВУГУ, 1996.

[5] Воеводін О.П. Регулятивна функція естетичного // Вісник державної академії керівних кадрів культури і мистецтв. - 2004. No 4. - C. 5-10.

[6] Галгаи A.Ю. Нравственная сублимация в процессе эстетического переживания // Практична філософія. - 2005. - o 4. - С. 34-40.

[7] Дмитриева Н.A. Краткая история искусств: Очерки. - Вып. 1. М.: Искусство, 1968.

[8] Ки.ященко Н.И., Лейзеров Н.Л. Теория отражения и проблемы эстетики. - М.: Искусство, 1983. 
[9] Коровин В.И. Искусство и мы. - М.: Знание, 1977.

[10] Луначарский А.В. Собрание сочинений. - Т. 4. - М.,1964.

[11] Моль A. Теория информации и эстетическое восприятие.- М.: Мир, 1966.

[12] Сеченов Н.М. Избранные философские и психологические произведения. - М.: Госполитиздат, 1947.

[13] Симонов П.В. Что такое эмоция? - М.: Наука, 1966.

[14] Филипьев Ю.А. Сигналы эстетической информации. - М.: Наука, 1971. 